Images in...

\title{
Swiss-cheese appearance of the brain in a young boy
}

\author{
Monica Gupta, S S Lehl, Ram Singh \\ Department of Medicine, Government Medical College and Hospital, GMCH Campus, Chandigarh, India \\ Correspondence to Monica Gupta, monicamanish2001@gmail.com
}

\section{DESCRIPTION}

A 14-year-old boy presented to our emergency department with status epilepticus of 1-h duration. He also had multiple episodes of generalised tonic-clonic seizures and intermittent headache for the past 1 month. He was a school dropout and belonged to a poor socioeconomic background. On examination, he was deeply comatose. Initial investigations included an axial contrast-enhanced CT of the brain subsequently followed by MRI of the brain.

CT brain demonstrated diffuse cerebral oedema with multiple small cystic lesions scattered bilaterally (figure 1). $M R$ images revealed innumerable well-defined small-sized cystic lesions (low signal on T1 and increased intensity on T2) and few, with tiny intralesional calcified, foci (typical appearance of scoleces) in the bilateral brain parenchyma with significant white matter oedema in the frontal regions (figures 2 and 3). These findings on the MR images were

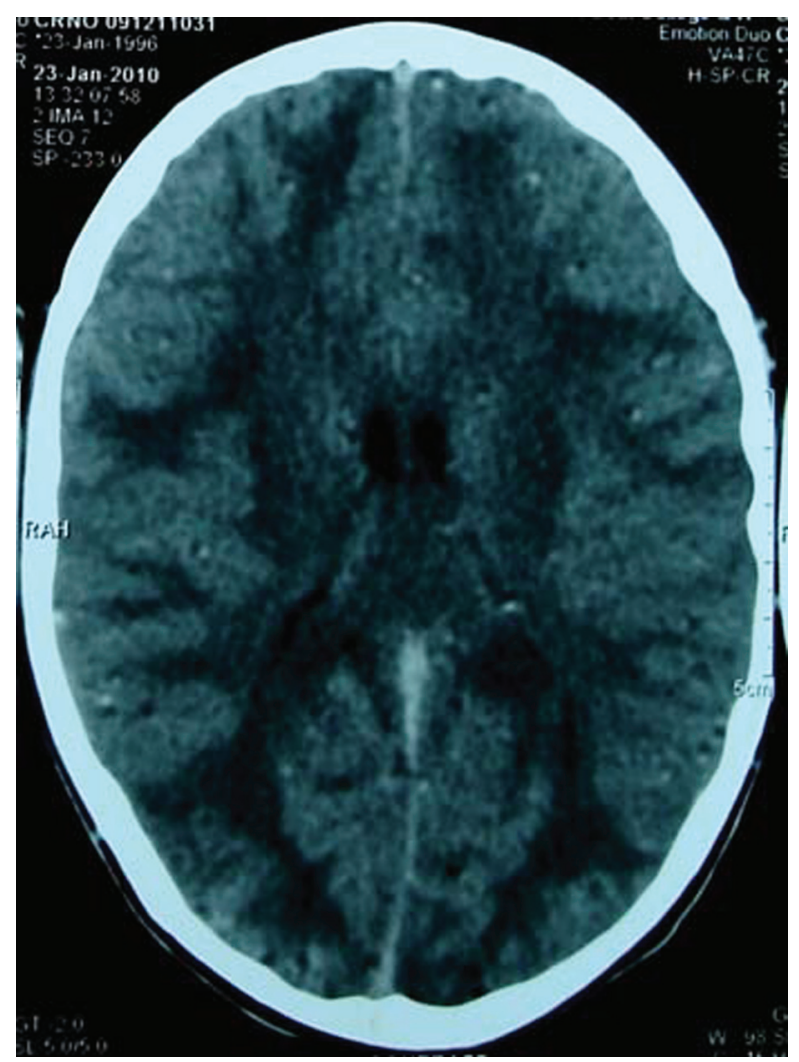

Figure 1 CT brain showing diffuse cerebral oedema with multiple small cystic lesions scattered bilaterally. pathgnomonic of neurocysticercosis and resembled the picture of Swiss-cheese.

Serum was positive for cysticercus immunoglobulin G antibodies by ELISA (1.60 optical density (OD) units; reference range, $<0.9 \mathrm{OD}$ units). There was no evidence of cysticerci in the thighs, subcutaneous tissues or the posterior segment of the eye. The patient was treated with intravenous antiepileptic drugs, glucocorticoids and antioedema measures. Subsequently after $48 \mathrm{~h}$, the patient was started on albendazole $400 \mathrm{mg}$ twice a day, which was continued for 21 days. Patient showed significant improvement and remained seizure-free during hospitalisation. A repeat CT brain done 1 week later showed a decrease in the cerebral oedema.

Neurocysticercosis is the most common parasitic disease of the central nervous system. Humans are the intermediate hosts of pork tape worm (Taenia solium). Cysticercosis is caused by ingesting the ova of the T solium through unhygienic vegetables or water. The diagnosis of cysticercosis is based on clinical, radiological and serological indicators. CT

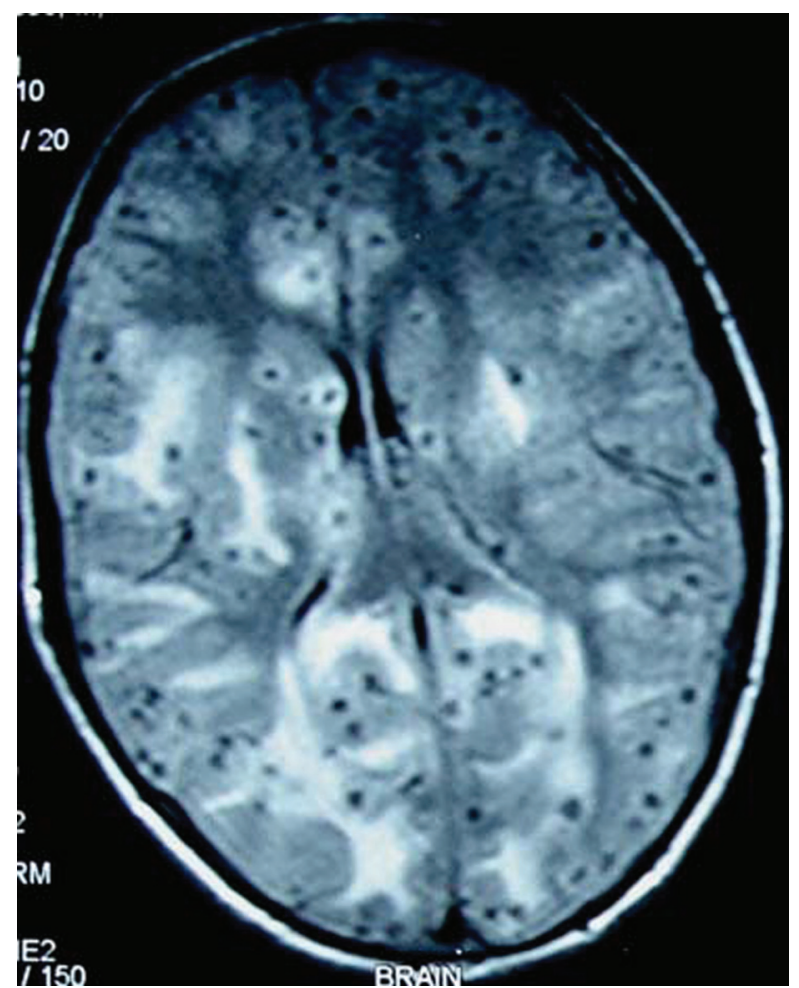

Figure 2 MR images with innumerable low-signal small-sized cystic lesions resembling Swiss-cheese. 


\section{BMJ Case Reports}

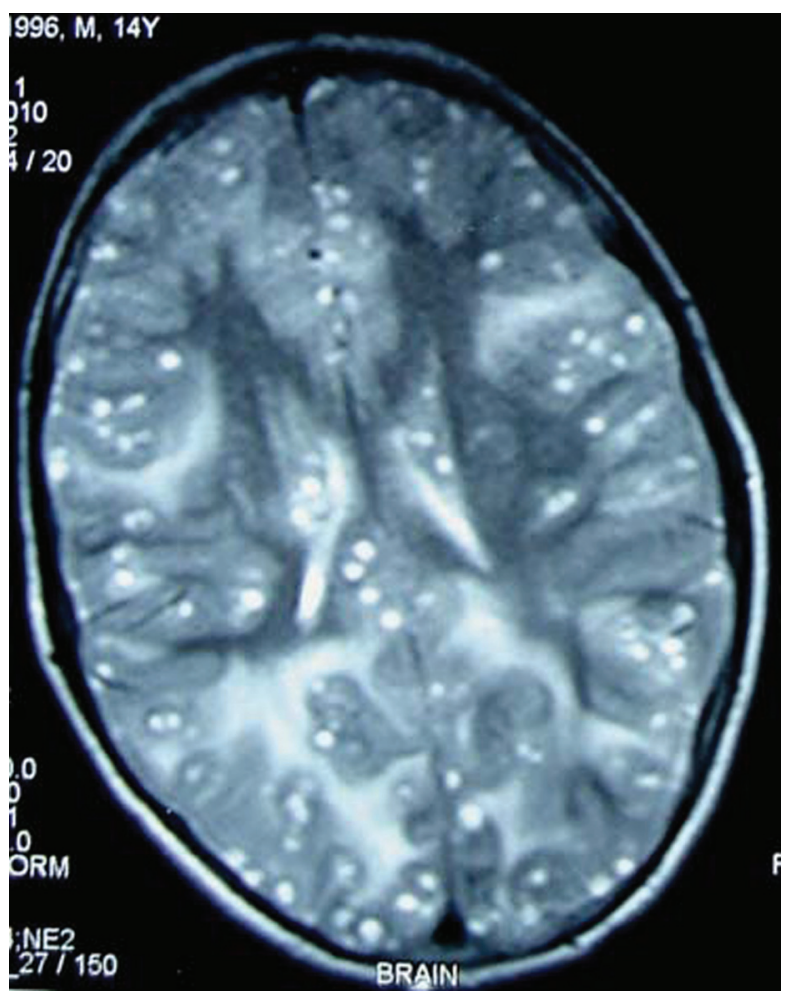

Figure 3 MRI brain showing multiple lesions with tiny intralesional calcified foci resembling starry sky. and MRI findings in parenchymal neurocysticercosis vary depending upon the stage of parasital development and the site of involvement, which may be parenchymal, intraventricular or meningobasal. Vesicular cysticerci appear as small, well-defined low-attenuation lesions (with eccentric hyperdense nodule interiorly representing the scolex) lacking perilesional oedema and enhancement after contrast medium administration. On MRI vesicular stage, scolex is usually visualised within the cyst as a high-intensity nodule giving the lesion a pathognomonic 'hole-with-dot' imaging and sometimes as in our case, these parasites are so numerous that the brain resembles a 'Swiss-cheese' or 'starry sky'. 1

Praziquantel and albendazole are the two antiparasitic drugs that have been reported to be effective against cerebral parenchymal cysticercosis lesions. ${ }^{2}$ However, albendazole is potentially more efficacious in treating the subarachnoid, ventricular and spinal cysts. In order to minimise the risks associated with the anticysticercal treatment (cerebral oedema, vasculitis), it is important to administer corticosteroids concomitantly, especially if there is high parasite load.

\section{Competing interests None.}

Patient consent Obtained

\section{REFERENCES}

1. Gracia $\mathbf{H H}$, Del Brutto $\mathrm{OH}$. Imaging findings in neurocysticercosis. Acta Tropica 2003;87:71-8.

2. Garg RK. Medical management of neurocysticercosis. Neurol India 2001;49:329-37.

This pdf has been created automatically from the final edited text and images.

Copyright 2011 BMJ Publishing Group. All rights reserved. For permission to reuse any of this content visit http://group.bmj.com/group/rights-licensing/permissions.

BMJ Case Report Fellows may re-use this article for personal use and teaching without any further permission.

Please cite this article as follows (you will need to access the article online to obtain the date of publication).

Gupta M, Lehl SS, Singh R. Swiss-cheese appearance of the brain in a young boy. BMJ Case Reports 2011;10.1136/bcr.12.2010.3598, date of publication

Become a Fellow of BMJ Case Reports today and you can:

- Submit as many cases as you like

- Enjoy fast sympathetic peer review and rapid publication of accepted articles

- Access all the published articles

- Re-use any of the published material for personal use and teaching without further permission

For information on Institutional Fellowships contact consortiasales@bmjgroup.com

Visit casereports.bmi.com for more articles like this and to become a Fellow 